\title{
Measurement of serum parathyroid hormone, with particular reference to some infants with hypocalcaemia
}

\author{
ANGELA FAIRNEY, * DOREEN JACKSON, and BARBARA E. CLAYTON \\ From the Department of Chemical Pathology, The Hospital for Sick Children and \\ Institute of Child Health, London
}

Fairney, A., Jackson, D., and Clayton, B. E. (1973). Archives of Disease in Childhood, 48, 419. Measurement of serum parathyroid hormone, with particular reference to some infants with hypocalcaemia. Parathyroid hormone (PTH) in serum has been determined by a double antibody radioimmunoassay which is suitable for use in infants. The concentration in normal infants rose after birth from a mean level of $97 \mathrm{pg} / \mathrm{ml}$ in cord blood to $217 \mathrm{pg} / \mathrm{ml}$ at 6 days of age. It remained at this level in the older infants and children. In a group of infants with hypocalcaemia and many complicating factors, the PTH concentration was significantly lower than normal. All but one of the affected infants maintained a normal serum calcium without treatment 1 year after the episode of hypocalcaemia. It is suggested that prolonged immaturity of parathyroid function may contribute significantly to the aetiology of hypocalcaemia and may be related to immaturity of the mechanisms responsible for converting glandular PTH to secreted PTH.

An increase in the number of neonates with hypocalcaemia has been reported (Baum, Cooper, and Davies, 1968; Begum, Yudkin, and Dormandy, 1968; Eades, 1968; Pugh, 1968). The decline of breast feeding and the use of artificial milks with a high content of phosphate appear to be aetiological factors. It is possible that abnormal function of the parathyroids may be important too, but the lack of an easily available sensitive assay for parathyroid hormone (PTH) has made it difficult to study the role of the parathyroid glands in hypocalcaemia of infants.

This paper reports a radioimmunoassay for serum PTH which has been adapted from the standard double antibody technique for growth hormone (Morgan and Lazarow, 1963; Jackson, Grant, and Clayton, 1968), which requires only micro quantities of serum, and which used an antiserum known to cross-react with human PTH. Since the method is capable of measuring normal values in the neonate, it has been used to study hypocalcaemia in a series of complex infants referred to The Hospital for Sick Children.

Received 26 September 1972.

^Present address: Department of Chemical Pathology, Page Street Wing, Westminster Medical School, 17 Page Street, London S.W.1.

\section{Patients and methods}

Blood samples and subjects. Capillary bloot samples were obtained by heel prick from 13 babies with hypocalcaemia. They were mostly unusual compared with infants with classical neonatal hypocalcaemia and had many complicating features. The clinical details are shown in Table I. During th: interval between the age at which hypocalcaemia was first diagnosed and the age at which PTH was measured (see Table VI), hypocalcaemia persisted or was intermittently corrected by treatment. In order to establish a normal range, assays were also performed on cord bloods from healthy infants, on capillary blood obtained by heel prick on the 6th day of life at the time of the Guthrie test in healthy babies, on capillary blocd obtained from older babies and children thought to have normal parathyroid function when they were having blood collected for other tests, and on samples from healthy adult volunteers. Blood was also obtained from 12 adults with hypoparathyroidism resulting from surgery. Blood was allowed to clot for less than 2 hours at room temperature, the serum being separated by centrifugation and stored at $-20^{\circ} \mathrm{C}$ in acid-washed glass bottles until required for assay. Whenever possible, plasma was collected for estimation of calcium.

Estimation of calcium. Plasma calcium was measured by atomic absorption in all subjects except in 
TABLE I

Clinical details of babies with hypocalcaemia

\begin{tabular}{|c|c|c|c|c|c|c|}
\hline $\begin{array}{c}\text { Case } \\
\text { no. }\end{array}$ & Clinical presentation & $\begin{array}{l}\text { Reason for } \\
\text { estimating } \\
\text { plasma } \\
\text { calcium }\end{array}$ & $\begin{array}{l}\text { Age at } \\
\text { which } \\
\text { hypocalcaemia } \\
\text { was first } \\
\text { diagnosed } \\
\text { (dy) }\end{array}$ & Associated lesions & $\begin{array}{c}\text { Treatment } \\
\text { at this } \\
\text { hospital for } \\
\text { hypocalcaemia }\end{array}$ & $\begin{array}{l}\text { Treatment } \\
\text { required } 1 \\
\text { year later to } \\
\text { maintain } \\
\text { normal } \\
\text { calcium }\end{array}$ \\
\hline \multicolumn{7}{|l|}{ Boys } \\
\hline 1 & $\begin{array}{l}\text { Vomiting from } 2 \text { dy of age; } \\
\text { convulsions from } 6 \mathrm{dy} \\
\text { of age }\end{array}$ & Convulsions & 10 & Nil & Ca!cium & Nil \\
\hline 2 & $\begin{array}{l}\text { Convulsions at } 8 \mathrm{dy} \text { of age, } \\
\text { followed by heart failure }\end{array}$ & Twitching & 18 & $\begin{array}{l}\text { Atrial septal defect; } \\
\text { ventricular septal defect; } \\
\text { persistent ductus } \\
\text { arteriosus; preductal } \\
\text { coarctation; partial } \\
\text { anomalous venous drainage }\end{array}$ & Calcium & Died \\
\hline 3 & $\begin{array}{l}\text { Acute renal failure after i.v. } \\
\text { pyelogram for urinary } \\
\text { retention; twitching } \\
\text { developed }\end{array}$ & $\begin{array}{l}\text { Routine } \\
\text { estimation }\end{array}$ & 5 & $\begin{array}{l}\text { Congenital hydronephrosis; } \\
\text { congenital hypothyroidism; } \\
\text { congenital hypopara- } \\
\text { thyroidism }\end{array}$ & $\begin{array}{l}\text { Calcium and } \\
\text { vitamin D }\end{array}$ & Nil \\
\hline 4 & Cyanosed $24 \mathrm{hr}$ after birth & Convulsions & 11 & $\begin{array}{l}\text { Transposition of great } \\
\text { arteries; ventricular } \\
\text { septal defect; probably } \\
\text { pulmonary stenosis }\end{array}$ & Calcium & Nil \\
\hline 5 & $\begin{array}{l}\text { Floppy baby with odd facies } \\
\text { and heart failure; referred } \\
\text { to this hospital } 7 \text { wk, hypo- } \\
\text { calcaemia still present }\end{array}$ & $\begin{array}{l}\text { Routine } \\
\text { estimation }\end{array}$ & 2 & Pulmonary atresia & $\begin{array}{l}\text { Calcium and } \\
\text { SMA }\end{array}$ & Nil \\
\hline 6 & $\begin{array}{l}\text { Progressive cyanosis after } \\
\text { birth }\end{array}$ & $\begin{array}{l}\text { Twitching } \\
\text { after } \\
\text { surgery for } \\
\text { diaphrag- } \\
\text { matic } \\
\text { hernia }\end{array}$ & 1 & $\begin{array}{l}\text { Right diaphragmatic hernia } \\
\text { left cleft lip and palate }\end{array}$ & Calcium & Nil \\
\hline 7 & Tachycardia; heart failure & Convulsions & 5 & $\begin{array}{l}\text { Nil; no cardiac lesion } \\
\text { found }\end{array}$ & $\begin{array}{c}\text { Calcium and } \\
\text { vitamin D }\end{array}$ & Nil \\
\hline 8 & $\begin{array}{l}\text { Snuffles; apnoeic attacks; } \\
\text { referred to this hospital at } \\
7 \text { wk for persistent hypo- } \\
\text { calcaemia; receiving Cow } \\
\text { and Gate }\end{array}$ & Twitching & 30 & Nil & $\begin{array}{l}\text { Changed to } \\
\text { SMA }\end{array}$ & Nil \\
\hline 9 & $\begin{array}{l}\text { Poor feeder; vomiting from } \\
\text { 4th dy; convulsions from } \\
5 \text { th dy; transferred to this } \\
\text { hospital at } 6 \text { wk for } \\
\text { persistent hypocalcaemia }\end{array}$ & Convulsions & 5 & $\begin{array}{l}\text { Bronchopneumonia with } \\
\text { severe bronchospasm; } \\
\text { repair of left inguinal } \\
\text { hernia; hypopara- } \\
\text { thyroidism }\end{array}$ & $\begin{array}{l}\text { SMA and } \\
\text { calcium } \\
\text { supple- } \\
\text { ments con- } \\
\text { tinued; } \\
\text { dose of } \\
\text { vitamin D } \\
\text { increased }\end{array}$ & $\begin{array}{l}\text { Oral } \\
\text { calcium } \\
\text { and } \\
\text { vitamin } \\
\text { D }\end{array}$ \\
\hline \multicolumn{7}{|l|}{ Girls } \\
\hline 10 & $\begin{array}{l}\text { Increasing cyanosis from } \\
\text { 3rd day }\end{array}$ & $\begin{array}{l}\text { Convulsion } \\
\text { after } \\
\text { cardiac } \\
\text { catheteri- } \\
\text { zation at } \\
6 \text { dy of age }\end{array}$ & 6 & $\begin{array}{l}\text { Transposition of great } \\
\text { arteries; ventricular } \\
\text { septal defect; mental } \\
\text { retardation }\end{array}$ & Calcium & Nil \\
\hline 11 & Feeding difficulties & $\begin{array}{l}\text { Respiratory } \\
\text { arrest }\end{array}$ & 2 & $\begin{array}{l}\text { Tracheo-oesophageal fistula; } \\
\text { hydrocephalus }\end{array}$ & Calcium & Nil \\
\hline 12 & Feeding difficulties & Convulsions & 4 & $\begin{array}{l}\text { Oesophageal atresia without } \\
\text { tracheo-oesophageal } \\
\text { fistula; stenosis, lactose } \\
\text { intolerance }\end{array}$ & Calcium & Nil \\
\hline 13 & Twitching & Twitching & 4 & Nil & $\begin{array}{l}\text { Calcium and } \\
\text { vitamin D }\end{array}$ & Nil \\
\hline
\end{tabular}

the normal babies in whom insufficient sample was available. Using an Eppendorf flame photometer, similar normal infants gave values for infants who were breast fed and those who were artificially fed on the first day of life of $8 \cdot 1 \pm 0.5$ and $8 \cdot 3 \pm 0.4 \mathrm{mg} / 100 \mathrm{ml}$ (mean $\pm S D$ ), respectively, rising to $8 \cdot 7 \pm 0.9$ and $9 \cdot 2 \pm 0 \cdot 3$ on the 8 th day (T. M. Barratt, unpublished observations). 
Assay of parathyroid hormone. Materials used included (1) iodination (a) highly purified bovine PTH (b.PTH), * (b) ${ }^{125} \mathrm{I}$; † (2) standard (a) b.PTH, purified on Sephadex, 2000 MRC units/mg (b.PTH), (b) serum from a patient with primary hyperparathyroidism (kindly donated by Professor C. E. Dent); (3) antiserum; guinea-pig antiserum to b.PTH; $\ddagger$ (4) precipitating serum; antiguinea-pig $\gamma$-globulin from rabbits; (5) 3 diluents were used in the system: A was hypoparathyroid serum (kindly donated by Dr. W. H. Taylor and Professor C. E. Dent) and was used for the standard curve and any test sera requiring further dilution; $B$ was veronal buffer $(0.1 \mathrm{~mol} / \mathrm{l}$.) + hypoparathyroid serum $(6: 1)$ and was used for the antiserum and labelled PTH; C consisted of 2 parts diluent B, 1 part $0.1 \mathrm{~mol} / 1$. EDTA and $1: 1000$ normal guinea-pig serum and was used to equalize incubation volumes. Parathyroid hormone was labelled with ${ }^{125} \mathrm{I}$ by a modified Hunter and Greenwood technique (Greenwood, Hunter, and Glover, 1963; Yalow and Berson, 1966; J. S. Woodhead, personal communication, 1971), stored in aliquots at $-20^{\circ} \mathrm{C}$ and diluted for the assay so that $30 \mu \mathrm{l}$ labelled hormone gave 100 counts per second. The labelled material produced 75 to $80 \%$ counts bound in the presence of excess PTH antibody and less than $10 \%$ counts bound in the absence of PTH antibody. The assay procedure is shown in Table II. The control

TABLE II

Assay procedure for PTH

\begin{tabular}{|c|c|}
\hline Solution & Volume $(\mu \mathrm{l})$ \\
\hline $\begin{array}{l}\text { Antiserum } 1: 40,000 \\
\text { Standard PTH: } 50-3,200 \mathrm{pg} \mathrm{ml} \mathrm{b.PTH} \mathrm{or} \\
\text { dilutions of primary hyperparathyroid serum } \\
\text { or patient samples } \\
\text { Diluent C } \\
\quad \text { Preincubate at } 4{ }^{\circ} \mathrm{C} \text { for } 24 \mathrm{hr}\end{array}$ & $\begin{array}{r}100 \\
50 \\
50 \\
250\end{array}$ \\
\hline $\begin{array}{l}{ }^{125} \text { I PTH } \\
\text { Incubate at } 4^{\circ} \mathrm{C} \text { for } 72 \mathrm{hr}\end{array}$ & 30 \\
\hline $\begin{array}{l}\text { Prezipitating serum } \\
\text { Incubate at } 4^{\circ} \mathrm{C} \text { for } 24 \mathrm{hr}\end{array}$ & 50 \\
\hline
\end{tabular}

Centrifuge twice at $1500 \mathrm{~g}$ for 15 minutes after washing with veronal buffer; count precipitate for 100 seconds.

b.PTH, bovine parathyroid hormone.

^Wilson Laboratories, Chicago, U.S.A.

†Radio Chemical Centre, Amersham, Bucks, U.K.

† Gift from Wellcome Research Laboratories, Beckenham, Kent, and Division of Biological Standards, Mill Hill, London. incubation consisted of 'buffer blanks' composed of $400 \mu \mathrm{l}$ diluent $\mathrm{C}+$ labelled hormone + precipitating serum. Two sera, one of known high $\mathrm{PTH}$ value and one of low, were included in each assay. When sufficient serum was available 'serum blanks' composed of $1: 2$ dilution of serum to be assayed + diluent $\mathrm{C}+$ labelled hormone + precipitating serum were included for each patient. The reliability of the assay was assessed by performing recovery experiments (see Table III). The coefficient of variation was $39 \%$ using values obtained from samples in duplicate assays, $23 \%$ using values obtained from samples assayed at different dilutions, and, using two different sera assayed in 11 consecutive assays, was $29 \%$ and $8.8 \%$. The lower limit of sensitivity for the assay was $39 \mathrm{pg}$ b.PTH/ $\mathrm{ml}$.

\section{Results}

The concentrations of serum PTH are shown in the Fig. Further details concerning the normal infants are given in Tables IV and V. The PTH

TABLE IV

Serum PTH in normal neonates

\begin{tabular}{l|c|c}
\hline \multicolumn{1}{c|}{ Feed $^{\star}$} & Serum PTH $(\mathbf{p g} / \mathbf{m l}$ b.PTH $)$ \\
\cline { 2 - 3 } & Cord blood & 6th day \\
\hline Boys & & \\
Breast & 10 & 310 \\
Breast & 200 & 410 \\
SMA & 35 & 155 \\
Ostermilk & 75 & 140 \\
SMA & 30 & 125 \\
Cow and Gate & 90 & 225 \\
SMA & 390 & 220 \\
Girls & & \\
Ostermilk & 25 & 215 \\
Ostermilk & 180 & 310 \\
SMA & 60 & 135 \\
SMA & 165 & 220 \\
Breast & 60 & 150 \\
Breast & 40 & 205 \\
SMA & detected & 220 \\
& & \\
\hline
\end{tabular}

$\star$ See Table VII.

concentration rose significantly $(P<0.01)$ from a mean level in cord blood of $97 \mathrm{pg} / \mathrm{ml}$ to 217 $\mathrm{pg} / \mathrm{ml}$ at 6 days of age, all except 1 infant showing the increase. There was no significant further

\begin{tabular}{|c|c|c|c|c|c|}
\hline & \multicolumn{5}{|c|}{ Amount of b.PTH added (pg) } \\
\hline & 50 & 150 & 300 & 600 & 1200 \\
\hline $\begin{array}{l}\text { Mean amount recovered } \\
\text { Mean \% recovered } \\
\text { No. of experiments }\end{array}$ & $\begin{array}{r}56 \\
112 \\
4\end{array}$ & $\begin{array}{c}149 \cdot 5 \\
99 \\
4\end{array}$ & $\begin{array}{l}355 \cdot 6 \\
118 \\
4\end{array}$ & $\begin{array}{r}627 \\
104 \\
4\end{array}$ & $\begin{array}{r}1218 \\
102 \\
4\end{array}$ \\
\hline
\end{tabular}




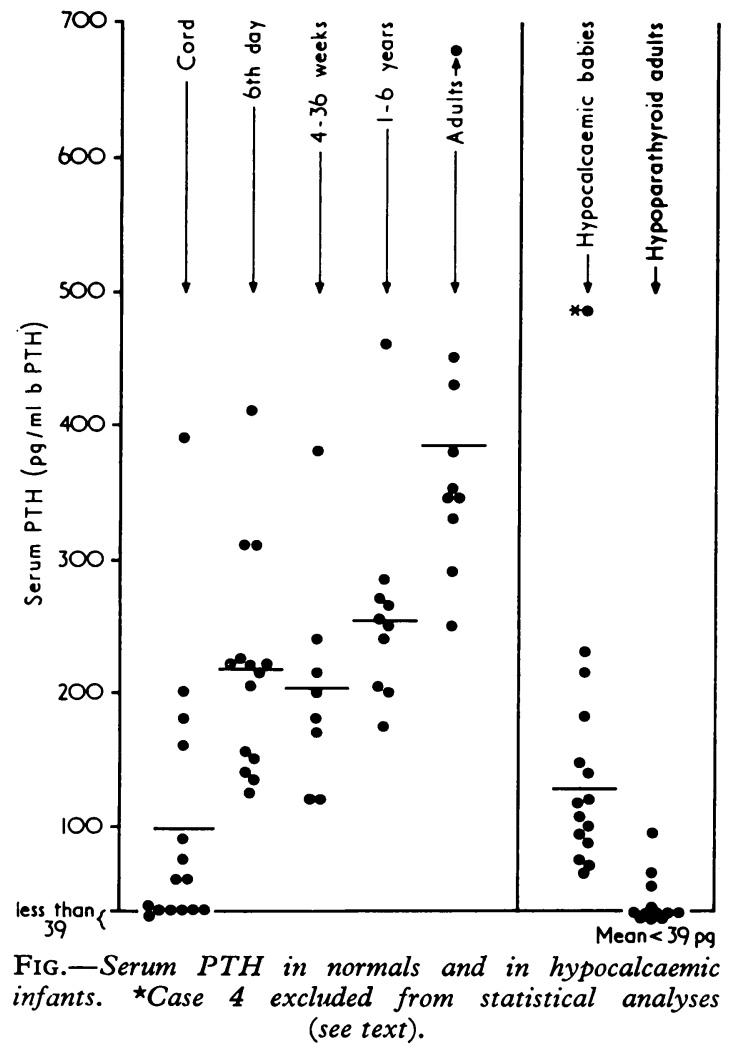

increase in the older infants or children aged 1 to 6 years. Levels in the adults were higher $(\mathrm{P}<0.001)$ compared with those in the infants and children.

Details of the infants with hypocalcaemia are
TABLE V

Serum PTH in older normal babies

\begin{tabular}{c|c|c|c}
\hline Case no. & Sex & Age (wk) & $\begin{array}{c}\text { Serum PTH } \\
(\mathbf{p g} / \mathbf{m l} \text { b.PTH })\end{array}$ \\
\hline 14 & M & 4 & 120 \\
15 & M & 6 & 240 \\
16 & F & 8 & 215 \\
17 & F & 12 & 200 \\
18 & M & 12 & 380 \\
19 & M & 24 & 180 \\
20 & F & 32 & 170 \\
21 & F & 36 & 120 \\
\hline
\end{tabular}

shown in Table VI. PTH concentrations were lower in this group $(P<0.01)$ compared with those found between 6 days and 36 weeks of age, the mean value being $130 \mathrm{pg} / \mathrm{ml}$ (excluding Case 4 who was probably recovering). The levels were not as low as those found in the adults with hypoparathyroidism. Analyses of the infants feeds are shown in Table VII.

\section{Discussion}

PTH has been measured in neonates and adults, and in children up to 6 years of age. Some time during later childhood or adolescence there must be a rise in PTH concentration in the serum, and this will require further study.

Classical neonatal tetany was first described by Kehrer in 1913 and subsequently shown to be associated with low serum calcium levels (Howland and Marriott, 1917). The babies in our study, however, did not form a homogeneous group and the majority were not considered to have the classical picture of neonatal hypocalcaemia. Their

TABLE VI

PTH and calcium concentrations in infants with hypocalcaemia

\begin{tabular}{|c|c|c|c|c|}
\hline Case no. & $\begin{array}{c}\text { Age at estimation } \\
(\mathrm{dy})\end{array}$ & Feed ${ }^{\star}$ & $\begin{array}{l}\text { Plasma Ca } \\
(\mathrm{mg} / 100 \mathrm{ml})\end{array}$ & $\underset{(\mathrm{pg} / \mathrm{ml} \text { b.PTH })}{\text { Serum PTH }}$ \\
\hline $\begin{array}{r}\text { Boys } \\
1 \\
2 \\
3 \\
4 \\
5 \\
6 \\
7 \\
8 \\
9\end{array}$ & $\begin{array}{r}10 \\
21 \\
25 \\
13 \\
53 \\
8 \\
40 \\
54 \\
48\end{array}$ & $\begin{array}{l}\text { Cow and Gate } \\
\text { ND } \\
\text { SMA } \\
\text { ND } \\
\text { Cow and Gate } \\
\text { ND } \\
\text { ND } \\
\text { SMA } \\
\text { Ostermilk }\end{array}$ & $\begin{array}{l}6 \cdot 9 \\
6 \cdot 4 \\
6 \cdot 2 \\
8 \cdot 8 t \\
5 \cdot 5 \\
5 \cdot 8 \\
4 \cdot 6 \\
6 \cdot 0 \\
4 \cdot 8\end{array}$ & $\begin{array}{r}75 \\
65 \\
216 \\
485 \\
118 \\
147 \\
107 \\
72 \\
88\end{array}$ \\
\hline $\begin{array}{l}10 \\
11 \\
12 \\
13\end{array}$ & $\begin{array}{r}11 \\
5 \\
8 \\
6\end{array}$ & $\begin{array}{l}\text { ND } \\
\text { Parenteral } \\
\text { Cow and Gate } \\
\text { Ostermilk }\end{array}$ & $\begin{array}{l}5 \cdot 8 \\
6 \cdot 8 \\
5 \cdot 8 \\
5 \cdot 1\end{array}$ & $\begin{array}{l}245 \\
100 \\
140 \\
182\end{array}$ \\
\hline
\end{tabular}

*See Table VII 
TABLE VII

Composition of milks

\begin{tabular}{|c|c|c|c|c|}
\hline \multirow{2}{*}{ Abbreviation } & \multirow{2}{*}{ Milk } & \multicolumn{3}{|c|}{ Composition of milk (mg/100 ml) } \\
\hline & & $\mathrm{Ca}$ & $\mathbf{P}$ & $\mathrm{Mg}$ \\
\hline $\begin{array}{l}\text { C \& G } \\
\text { ND } \\
\text { Ostermilk } \\
\text { SMA } \\
\text { BM }\end{array}$ & $\begin{array}{l}\text { Cow and Gate (full cream) } \\
\text { National Dried (full cream) } \\
\text { Ostermilk I } \\
\text { SMA } \\
\text { Breast milk }\end{array}$ & $\begin{array}{l}97 \cdot 2 \\
110 \\
106 \\
50 \\
29\end{array}$ & $\begin{array}{l}73 \cdot 9 \\
90 \cdot 8 \\
83 \cdot 6 \\
40 \\
14\end{array}$ & $\begin{array}{r}10 \cdot 1 \\
13 \cdot 4 \\
12 \cdot 3 \\
5 \cdot 0 \\
3 \cdot 0\end{array}$ \\
\hline
\end{tabular}

presentation was varied (see Table I) and there were many complicating factors.

Three mechanisms for the pathogenesis of neonatal tetany have been suggested (Bakwin, 1937): vitamin D deficiency, parathyroid hypofunction, and reaction to a high phosphate intake, the latter two being the subject of much subsequent debate and research. In 1942, Kaplan reported hypertrophy of the parathyroid glands in 14 out of 53 infants aged between birth and 30 days. In none was there evidence of renal disease or rickets. On reviewing the necropsy records (Gardner et al., 1950), the hypertrophy was found to be associated with an excessive intake of phosphorus from cow's milk feeds and the relation between artificial feeding and hypocalcaemia has been noted subsequently (Baum et al., 1968; Begum et al., 1968; Eades, 1968; Pugh, 1968; Oppé and Redstone, 1968).

Although radioimmunoassays for measuring PTH have undoubted limitations, helpful determinations have been reported from a number of centres (Berson et al., 1963; Reiss and Canterbury, 1968; Arnaud, Tsao, and Littledike, 1971; O'Riordan, Watson, and Woodhead, 1972). Shortage of materials of human origin, immunological differences between species, and the fact that native glandular hormone is immunologically different from secreted hormone (Arnaud, Tsao, and Oldham, 1970; Sherwood, Rodman, and Lundberg, 1970) all add to the problem of measuring PTH in patients.

Our study of hypocalcaemic infants showed that all were fed on artificial milks, that there was a preponderance of boys and a frequent association with congenital abnormalities of the thorax and reduced concentration of serum PTH. In spite of severe hypocalcaemia the parathyroid glands in these babies appeared to be incapable of responding to this stimulus by an increase in secretion of PTH. Unfortunately, blood samples for PTH assays were unavailable during the follow-up, but the maintenance of a normal serum calcium 1 year after the hypocalcaemic episode suggests that most of them had only a transient disturbance of parathyroid function. Some of our infants had features similar to those with transient congenital idiopathic hypoparathyroidism described by Fanconi and Prader (1967) in whom the aetiology was thought to be a primary congenital hypoplasia or dysplasia of the parathyroids with a subsequent compensatory hyperplasia.

Our results provide further evidence for a functional immaturity of the parathyroid glands which may be more prolonged in infants in whom hypocalcaemia develops. Though our results were obtained in a rather unusual group of infants, it seems likely that they would apply to a series of infants with classical neonatal hypocalcaemia and this requires further study. In view of the differences between glandular and secreted PTH, it is possible that functional immaturity may be related to hypofunction of enzymes concerned with the conversion of glandular PTH to secreted PTH. This cannot be studied until methods for measuring different types of PTH become available.

We thank many clinical colleagues for allowing us to study patients under their care; Dr. T. M. Barratt allowed us access to his unpublished data on plasma calciums in infants; gifts of materials were generously donated by Dr. W. Taylor, Professors F. T. G. Prunty and C. E. Dent, the Medical Research Council, and the Wellcome Research Laboratories; one of us (A.F). was the holder of the Walter Dixon Award of the British Medical Association, the Williams Fellowship for Medical and Scientific Research of the University of London, and a travel grant from the Wellcome Trust; financial support was provided by the Smith Kline and French Foundation and the Central Research Fund of the University of London; we are especially grateful to Dr. Claude Arnaud of the Mayo Clinic for much advice and gifts of materials.

\section{REFERENCES}

Arnaud, C. D., Tsao, H. S., and Littledike, T. (1971). Radioimmunoassay of human parathyroid hormone in serum. Fournal of Clinical Investigation, 50, 21.

Arnaud, C. D., Tsao, H. S., and Oldham, S. B. (1970). Native human parathyroid hormone: an immunochemical investigation. Proceedings of the National Academy of Sciences of the U.S.A., 67, 415. 
Bakwin, H. (1937). Pathogenesis of tetany of the newborn. American fournal of Diseases of Children, 54, 1211.

Baum, D., Cooper, L., and Davies, P. A. (1968). Hypocalcaemic fits in neonates. Lancet, 1, 598.

Begum, R., Yudkin, S., and Dormandy, T. L. (1968). Hypocalcaemic fits in neonates. Lancet, 1, 690.

Berson, S. A., Yalow, R. S., Aurbach, G. D., and Potts, J. T. (1963). Immunoassay of bovine and human parathyroid hormone. Proceedings of the National Academy of Sciences of the U.S.A., 49, 613.

Eades, S. (1968). Hypocalcaemic fits in neonates. Lancet, 1, 644.

Fanconi, A., and Prader, A. (1967). Transient congenital idiopathic hypoparathyroidism. Helvetica Paediatrica Acta, 22, 342.

Gardner, L. I., MacLachlan, E. A., Pick, W., Terry, M. L., and Butler, A. M. (1950). Aetiologic factors in tetany of newly born infants. Pediatrics, 5, 228.

Greenwood, F. C., Hunter, W. M., and Glover, J. S. (1963). The preparation of 131 I-labelled human growth hormone of high specific radioactivity. Biochemical fournal, 89, 114.

Howland, J., and Marriott, W. M. (1917). Observations upon the calcium content of the blood in infantile tetany and upon the effect of treatment by calcium. Quarterly fournal of Medicine, $11,289$.

Jackson, D., Grant, D. B., and Clayton, B. E. (1968). A simple oral test of growth-hormone secretion in children. Lancet, $2,373$.

Kaplan, E. (1942). The parathyroid gland in infancy. Archives of Pathology, 34, 1042.
Kehrer, E. (1913). Die geburtshilflich-gynäkologische Bedeutung der Tetanie. Archiv für Gynäkologie, 99, 372.

Morgan, C. R., and Lazarow, A. (1963). Immunoassay of insulin: two antibody system. Diabetes, 12, 115.

Oppé, T. E., and Redstone, D. (1968). Calcium and phosphorus levels in healthy newborn infants given various types of milk. Lancet, 1, 1045.

O'Riordan, J. L. H., Watson, L., and Woodhead, J. S. (1972). Secretion of parathyroid hormone in primary hyperparathyroidism. Clinical Endocrinology, 1, 149.

Pugh, R. J. (1968). Hypocalcaemic fits in neonates. Lancet, 1, 644

Reiss, E., and Canterbury, J. M. (1968). A radioimmunoassay for parathyroid hormone in man. Proceedings of the Society for Experimental Biology and Medicine, 128, 501.

Sherwood, L. M., Rodman, J. S., and Lundberg, W. B. (1970) Evidence for a precursor to circulating parathyroid hormone. Proceedings of the National Academy of Sciences of the U.S.A., 67, 1631.

Yalow, R. S., and Berson, S. A. (1966). Purification of ${ }^{131}$ I parathyroid hormone with microfine granules of precipitated silica. Nature (London), $212,357$.

Correspondence to Professor Barbara E. Clayton, The Hospital for Sick Children, Great Ormond Street, London WC1N 3JH. 